\title{
Analysis of the Competitiveness of Teak Wood Export in Togo (West Africa)
}

\author{
Komla Mensah Gatonnou \\ Adzo Dzifa Kokutse \\ Kouami Kokou
}

Laboratoire de Botanique et Ecologie Végétale,

Département de Botanique, Faculté des Sciences (FDS), Université de Lomé, Togo

Egnonto M. Koffi-Tessio

Laboratoire de Recherche sur la Pauvreté et la Sécurité Alimentaire (LARPSAD), Ecole Supérieure d'Agronomie (ESA), Université de Lomé, Togo

Akoété Ega D. Agbodji

Faculté des Sciences Economiques et de Gestion (FASEG), Université de Lomé, Togo

doi: 10.19044/esj.2017.v13n1p134 $\quad$ URL:http://dx.doi.org/10.19044/esj.2017.v13n1p134

\begin{abstract}
The log export ban in favor of value-added wood products remains a challenge for developing countries in the context of maximizing national income from international timber trade at the expense of sustainable forest management. This study attempts to shed light on this subject matter through an analysis of the competitiveness of teak wood in Togo. The policy analysis matrix was developed using teak exporter budgets with reference to national and international market prices collected in July and August 2014. The results show that Togo has no comparative advantage in the squared teak trade which is the result of processing teak in Togo, whatever the level of price observed during this period. On the other hand, it is better for Togo to sell its log on the international market when the price reached $542 \mathrm{USD} / \mathrm{m}^{3}$ (maximal price observed). Togo does not sufficiently protect its national market to maximize income for exporters.
\end{abstract}

Keywords: Togo, teak, competitiveness, policy analysis matrix, market protection 


\section{Introduction}

Forest taxation aims at contributing, among other things, to State and Community fiscal revenues promoting local industrialization and timber processing, and achieving sustainable forest management (Guéneau, 2004). According to Karsenty (2000), the fiscal instruments of forest taxation are royalties, stumpage and other taxes such as those on exports. Royalties are proportional to the area of exploited concession and stumpage is based on wood volume. Export-related taxes include customs duties and export license fees. Moreover, within the framework of the promotion of local industrialization and a more elaborate processing of wood, the policy instruments are a total or partial ban (or quota) on the export of logs. Sometimes, these instruments are in the form of differential taxation on the decision to process or not to process wood products. In this case, these fiscal instruments are designed to create jobs and value added in the country. According to the OAB (2004), in Africa, one of the most used instruments for stimulating industrialization and processing of timber is the export ban and the minimum quota on local processing of logs. Indeed, some studies relate the log export ban or restriction to promoting industrialization, increasing the value of wood and the welfare of producers (Tachibana, 2000; Kishor and al., 2004; Resosudarmo and Arief, 2006; Amoah and al., 2009; Van Kooten, 2014). In this perspective, Cameroon in 1999 and Gabon in 2010 banned the export of logs (Ed Perry and Abediang, 2009; ITTO, 2010; Kaplinsky and al., 2011). Sometimes these restrictive policies are limited to specific species as in the case of Togo, which imposes, since 1988, a moratorium on the export of timber from natural forests. However, these measures applied to encourage industrialization in the wood sector in the country are controversial. Indeed, according to the neoclassical approach, banning or restricting log export from developing countries is a bad allocation of this resource because of the very low yield of timber processing on site (Goodland and Daly, 1996, Karsenty and Piketty, 1996). The opponents of the ban and restriction argue that these policies contribute to lower domestic log prices, incomes of farmers and government revenues. Obviously, the application of a log export ban policy depends on the comparative advantage that a country has in exporting both types of wood i.e. logs and processed wood products.

In Togo, forest taxation takes the form of differential taxation in order to encourage local industrialization in the timber sector. To this end, Decree No. 041 / MERF / SG of December 5, 2011 regulating the export and re-export of teak and other forest species in the country serves as fiscal incentive. Despite the application of this ordinance, the export of unprocessed teak remains on the rise. Indeed, between 2013 and 2014, Togo exported 30,550 $\mathrm{m}^{3}$ of teak of which $88.97 \%$ as logs and $11.03 \%$ in the squared form which is the product of processed timber in the country (Gatonnou and al., 2015). As a 
consequence, it is timely to investigate which of these two products is more competitive on the international teak market.

This purpose of this paper is to analyze the impact of forest taxation on the level of competitiveness of teak export in Togo. Specifically, it assesses the effect of this fiscal regime on international trade in logs and squared teak at the international market prices of 2014. The indicators selected for this purpose are (i) the nominal protection coefficient (NPC), (ii) the effective protection coefficient (EPC) and (iii) the domestic resource cost (DRC) and subsidy rate (SR) (Monke and Pearson, 1989; Allaya and Karray, 2000; Talleck and Bockel, 2005; Aquilas and al., 2013).

\section{Methodology}

\section{Overview of the study environment}

This study was conducted in Togo (one of the West African countries) and especially in the "Gulf District", in the southwest of the Maritime Region (Figure 1). This district shares a border in the North with the Zio District, in the South with the Gulf of Guinea, in the East with the Lake District, in the West with Ghana and in the North with the Avé District. It covers an area of $280 \mathrm{~km}^{2}$ with $1,569,379$ inhabitants, that is, about $25.50 \%$ of the population of the country with approximately $51.88 \%$ women (DGSCN, 2013). The capital of the country, Lomé, is located in the Gulf District, with all the infrastructures and a high concentration of banks and other financial institutions.

The monography of the Gulf District reveals that most of the people are farmers outside of the municipality of Lomé $\left(90 \mathrm{~km}^{2}\right)$, which itself concentrates most of the non-agricultural jobs in the country. Most of the nonagricultural activities and non-administrative services are practiced in the informal sector (Department of Planning, 2009). These are essentially the wholesale, retail, distribution and redistribution, and other small businesses particularly handicrafts. The biggest corporations have their headquarters in Lomé which is the primary trading hub of the country. 

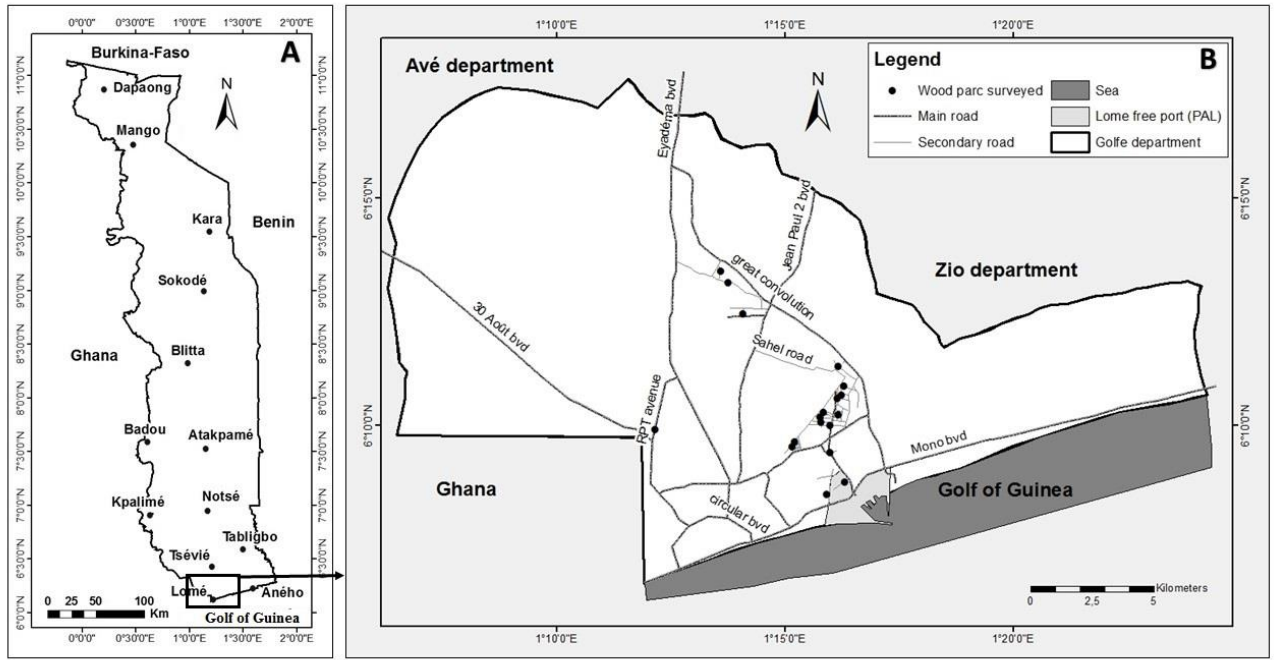

Figure 1: Map showing wood parks in the Gulf District (B)

Lomé hosts the Port Authority of Lomé (PAL) which is the shipping point for wood exports. The PAL favors the development of international trade and relieves the isolation of the hinterland countries (Burkina Faso, Mali, and Niger).

\section{Theoretical framework}

Based on the approach of the policy analysis matrix (PAM) developed by Monke and Pearson (1989), two types of budgets (financial budget (valued at market prices) and an economic budget (assessed with the reference prices on the international market) are computed as follows (table 1).

Table 1 : Structure of PAM

\begin{tabular}{|c|c|c|c|c|}
\hline & \multirow[b]{2}{*}{ Revenues } & \multicolumn{2}{|c|}{ Costs } & \multirow{2}{*}{ Profit } \\
\hline & & Tradable inputs & Domestic factors & \\
\hline Private prices & A & B & $\mathrm{C}$ & $\mathrm{D}$ \\
\hline Social prices & E & $\mathrm{F}$ & G & $\mathrm{H}$ \\
\hline Divergences & I & $\mathrm{J}$ & $\mathrm{K}$ & $\mathrm{L}$ \\
\hline
\end{tabular}

Source: Monke and Pearson (1989).

A, B, C, D are the financial elements of the budget and E, F, G, H are components of the social or economic budget. I, J, K, L correspond to differences between the two budgets and represent revenue transfers. Tradable inputs are the goods or services which can be sold on the international market and entering intermediate consumption. On the other hand, the non-tradable goods may not be subject to international trade. PAM allows determining indicators expressing the real exchanges (Dieng and al., 2011). 


\section{Indicators of the transfers}

They are output transfers (I), input transfers $(\mathrm{J})$, factor transfers $(\mathrm{K})$. The net transfers (L) correspond to income transfers minus tradable input and domestic factor transfers.

$I=A-E$

$J=B-F$

$K=C-G$

$L=D-H=I-J-K$
Equation 1

Equation 2

Equation 3

Equation 4

\section{Indicators of policy effects}

The effects of current policies are measured by the Nominal Protection Coefficient (NPC) and the Effective Protection Coefficient (EPC) and Subsidy rate (SR).

- NPC is the ratio of the market price to the social price of a good. $N P C=A / E$

Equation 5

- $\quad \mathrm{NPC}=1$ expresses the equilibrium point or the optimal level of competitiveness of trade between domestic and international markets. It means that the structure of protection is neutral. It implies that national actors are neither favoured nor disadvantaged.

- $\quad$ NPC $>1$ means that the good considered benefits from a protection with regard to the imported or exported good. It is a positive protection. Producers or exporters take advantage of a subsidy due to the intervention of a structure of protection:

- $\quad \mathrm{NPC}<1$. It is a negative protection of the national economy. It implies that the country does not protect its market. Producers or exporters are overtaxed and disadvantaged. In this case, producers or national exporters receive lower incomes than what they would gain in an economy in the context of international markets.

- EPC measures the combined effect of the price policies on products and tradable inputs on production incentives: $E P C=(A-B) /(E-F)$

Equation 6

- $\quad$ EPC $>1$ implies that operators of the chain of the considered activity gain more income than they would gain without price distortion.

- $\quad \mathrm{EPC}=1$ It is the equilibrium point or the optimal level of competitiveness of the trade between national and international markets. In this case, the protection is neutral.

- $\quad$ EPC $<1$ means that the country does not protect his market. In this case, national actors are disadvantaged on the national market.

- SR is the ratio expresses the net effect of the chain in terms of policies of subsidy and tax representing a proportion of social income:

$S R=L / E$

Equation 7 
- $\quad$ SR $>0$ means that the country protect this market and subsidizes exporters.

- $\quad \mathrm{SR}<0$ means that the country does not protect his market and imposes taxes to exporters.

\section{Indicator of comparative advantage}

It is related to the domestic resources costs (DRC). DRC measures the global efficiency of the activity and translates the opportunity cost of domestic resources.

$D R C=G /(E-F)$

Equation 8

- $\quad 0<\mathrm{DRC}<1$ means that there is comparative advantage in processing locally a given good with given technology than exporting it.DRC $>1$ means that there is no comparative advantage in processing locally a given good with given technology than export it..

- $\quad$ DRC $=1$ indicates that processing locally a given good with given good is as equally rewarding as exporting the raw materials.

\section{Empirical methods Data Collection}

The detailed prices were collected during a socio-economic survey realized between July and August of 2014 from 7 companies representing 62\% of the export market of teak wood in Togo between 2013 and 2014 (Gatonnou and al., 2015). Marketing costs, turnover and intermediate consumption data (IC) were collected according based on Shepherd's methology on the determination of marketing costs (Shepherd, 2007). The financial data were collected in XOF using a structured questionnaire using closed questions.

In the absence of data on teak reference price on the Chinese market, its price in India, provided by ITTO (2015) in the Tropical Timber Market Report has been used, because India is the second teak wood importing country from Togo (Gatonnou and al., 2014).

\section{Data processing}

The marketing costs and intermediate consumption of the exporting companies were classified into tradable and non-tradable goods. The reference prices of these goods were obtained from the detailed prices for accounting conversion coefficients. For that purpose, handling costs, fees and taxes, amortizations were distributed according to the conversion rates used by Coulibaly and al (2007) in the context of the analysis of the financial and economic impacts of the wood-energy sector. Even if wood and wood-energy are not perfectly substitutable firstly because, of the various uses to which they can be allocated and secondly because of the differences in the type of business in which they participated. The choice of these conversion coefficients is 
justified by the lack of information on parity prices on the load elements in the teak export market. This consideration implies the following assumptions:

- $\quad$ the teak intended for export can be substitutable for wood energy;

- $\quad$ the communication prices of the various operators in Togo are identical and are subjected to a value-added tax of $18 \%$ (VAT); the same for electricity; - $\quad$ the fumigation cost corresponds to a real consumption of goods which generates real advantages for the exporter because it ensures a good phytosanitary health of the wood to be exported with an invoicing of the VAT at $18 \%$ and a $20 \%$ profit margin for people receiving benefits;

- $\quad$ the domestic factors used by the exporting companies are estimated at their opportunity cost.

Moreover, because of the unavailability of the social price of squared teak wood from Togo, the one from Nigeria was chosen instead of those from Brazil and Ecuador for the evaluation of the competitiveness of squared teak from Togo because of their geographic proximity. For that purpose, we suppose that the quality of squared teak of the 2 countries is identical. The cost of the dollar on August 31st, 2014 (1 dollar is equal to 499.60 XOF) was used for the monetary evaluation of the volumes of wood exported using the reference prices published by ITTO (2015). The teak prices are being expressed in intervals; 2 scenarios were presented for the 2 products (log and squared teak). The first scenario proposes an analysis considering the minimal reference price and the second is based on the maximum reference price. For purposes of comparison, the analysis was made for a 20 - foot container.

\section{Results}

\section{World prices of teak at Indian seaports in August, 2014}

The price (including costs and freight) of teak logs on the international market depends on the country of origin of the wood. In August 2014, the lowest price at Indian seaports had been observed for exports from Panama $\left(253 \mathrm{USD} / \mathrm{m}^{3}\right)$ and the highest for exports from Salvador $\left(934 \mathrm{USD} / \mathrm{m}^{3}\right)$. For Africa, the lowest price at the mentioned ports had been recorded in Ghana $\left(255 \mathrm{USD} / \mathrm{m}^{3}\right)$ and the highest in Benin (775 USD/ $\left.\mathrm{m}^{3}\right)$. The prices of $\operatorname{logs}$ from Togo at Indian seaports were between 280 and 542 USD/m ${ }^{3}$ (Figure 2). 


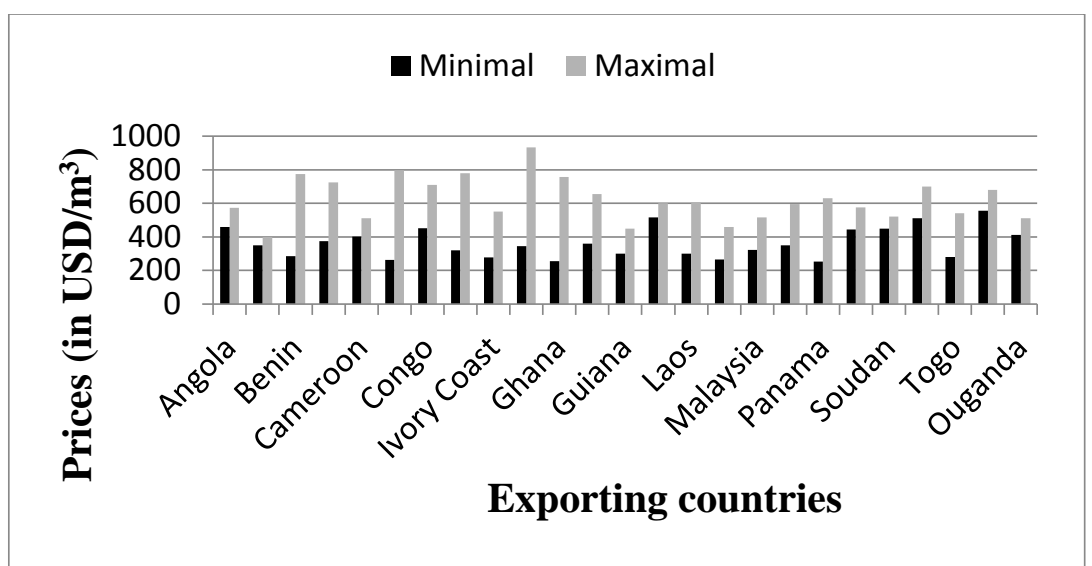

Figure 2: Teak log prices on arrival at Indian seaports (including costs and freights) between August 2014 and July 2015 (Data source: ITTO, 2015).

Concerning squared teak, the minimal and maximal prices were both negotiated at Ecuador at respectively 313 and $858 \mathrm{USD} / \mathrm{m}^{3}$. On the other hand, Nigeria negotiated her own prices at between 367 and $418 \mathrm{USD} / \mathrm{m}^{3}$ (Figure $3)$.

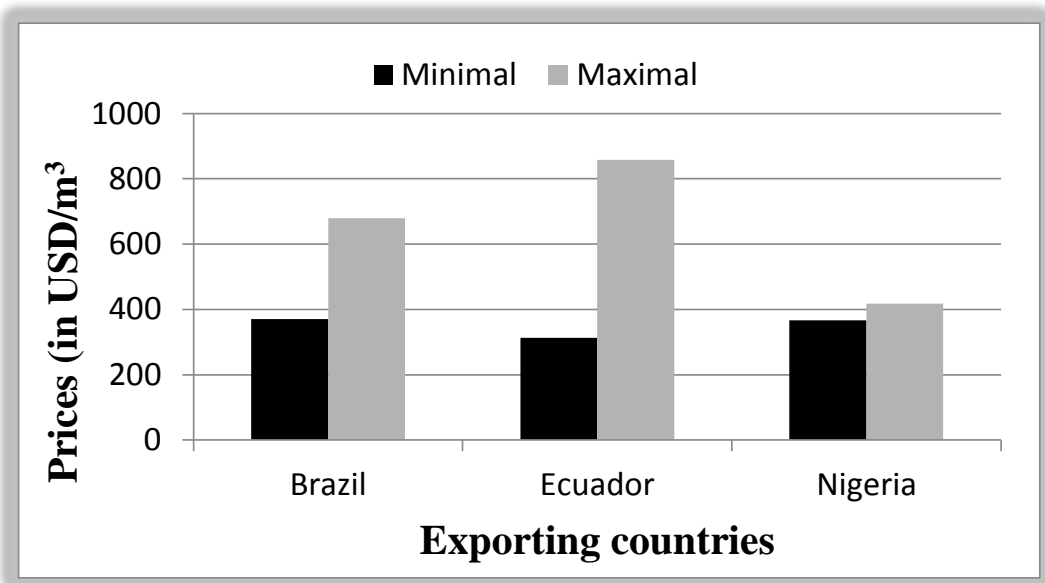

Figure 3: Squared teak prices on arrival at Indian seaports (including costs and freights) between August 2014 and July 2015 (Data source: ITTO, 2015)

\section{Analysis of the effects of economic policy on the export of teak in Togo Squared teak}

The calculation of the domestic resources costs (CDR) gives values superior to 1 in both cases: 1.71 for the first scenario and 1.25 for the second. It would mean that the value added on the export of squared teak at the market price is superior to the value added at the reference price. This configuration implies that processing locally squared teak does not induce comparative advantages for the country's economy whatever the scenario considered. 
Indeed, the social net profitability (SNP) induced by selling these products abroad, is negative in both cases. In the current exchange conditions, a sale abroad engenders a loss of 489530 XOF per container for scenario 1 and 234 734 XOF for scenario 2. It shows that this activity is not economically viable (table 2). However, the fiscal incentive (differentiated taxation) in favour of the transformation of teak wood before export has a positive effect on the export of these products (EPC $>1)$. Besides, the export of teak squares benefits from an implicit subsidy of about $39.89 \%$ and $22.82 \%$ respectively in scenarios 1 and 2. Without these subsidies, the losses will be greater in this sub sector. In this specific case, it is preferable for operators to sell their squared teak at the national level rather than on the international market. Table 2 below presents the indicators of appreciation of squared teak marketing incentives in Togo between 2013 and 2014.

Table 2 : Indicators of appreciation of squared teak marketing incentives

\begin{tabular}{ccc}
\hline Ratios & Scenario 1 & Scenario 2 \\
\hline Subsidy rate & $39.89 \%$ & $22.82 \%$ \\
NPC & 1.62 & 1.42 \\
EPC & 2.66 & 1.94 \\
CRD & 1.71 & 1.25 \\
\hline
\end{tabular}

Source: ITTO Reference data (2015) and field investigations

\section{Teak logs}

Similarly as for squared teak, when the price of teak logs on international markets is at its minimal level (scenario 1), their export does not either induce a comparative advantages for Togo. Indeed, the prices induce a CDR superior to 1 (2.84) and a negative SNP. By agreeing to export teak wood in these conditions, national exporters bear a loss of 662589 XOF per container. Besides, the calculations reveal an NPC and an EPC superior to 1, which are respectively 1.85 and 4.29 for scenarios 1 and 2 . Thus it seems that the national market benefits from a positive protection and it therefore offers a better possibility for the allocation of this resource, given that national companies take advantage of implicit incentive measures in favour of sales at the national level. These incentive measures are shown by a fictitious subsidy of $56.58 \%$ in the chain. It is expressed by maximal income earnings stemming from marketing in the current exchange situation for the local companies. Indeed, by selling on the international market at this price, exporters sustain a loss of 662589 XOF per container. In other words, they should rather sell their teak logs locally when the reference price of the product is minimal.

On the other hand, in scenario 2, the sale of teak logs on the international market induces a comparative advantage for the national economy with a CDR of 0.61 (lower than 1). Indeed, a high price allows national exporters to benefit from additional income of 517422 XOF per 
container when selling on the international market. In this situation, the calculated NPC and EPC are respectively 0.95 and 0.93 which are both less than 1. It means that Togo does not protect his market and exporters are disadvantaged compared to their counterparts who sell their products on the international market (negative subsidy rate of $19.11 \%$ ). Table 3 shows the indicators of appreciation of the incentive measures for the export of teak logs in Togo between 2013 and 2014.

Table 3 : indicators of appreciation of the incentives to export teak logs

\begin{tabular}{ccc}
\hline Ratios & Scenario 1 & Scenario 2 \\
\hline Subsidy rates & $56.58 \%$ & $-19.11 \%$ \\
NPC & 1.85 & 0.95 \\
EPC & 4.29 & 0.93 \\
CRD & 2.84 & 0.61 \\
\hline
\end{tabular}

Source: ITTO reference data (2015) and field investigations

\section{Discussion}

The calculation of the domestic resources costs (DRC) of squared teak and $\operatorname{logs}$ gives values superior to 1 except in the case of scenario 2 for logs, where the international price favours higher incomes than local sale. In other words, with the current conditions of exchange, it is not good for Togo to export squared teak. The reason transformed teak (squared teak) from Togo is not competitive on the international market could be due to the level of industrialization of its timber sector. Indeed, although the local transformation of the wood has positive effects on the creation of jobs and value added, it is the lack of material efficiency which harms a better competitiveness of transformed wood. Material losses during the primary processing could explain competitiveness failure from squared teak. Indeed, Akpoto and al. (2014) evaluate the performance of wood processing in Litimé (South-west of Togo) to $10.91 \%$.

In Togo, the processing industry of raw teak into squares depends on depreciated second hand machines from Europe (Figure 4). Therefore, for a better profitability of teak wood export, the country should rather encourage the export of the raw wood to the detriment of squared wood as transformation products; unless a policy of industrial development in the forest sector is put in place. This result is in agreement with the ideas of Karsenty and Piketty (1996) and with neo-classical thought according to which the ban or the restriction of the export of logs from developing countries constitutes a bad allocation of resources because of the very low efficiency of the local transformation of wood. It also confirms the result of Amoah and al. (2009) who, studying the impact of the policy on log export ban from Ghana, realized that this economic policy did not guarantee growth in wood product prices. 


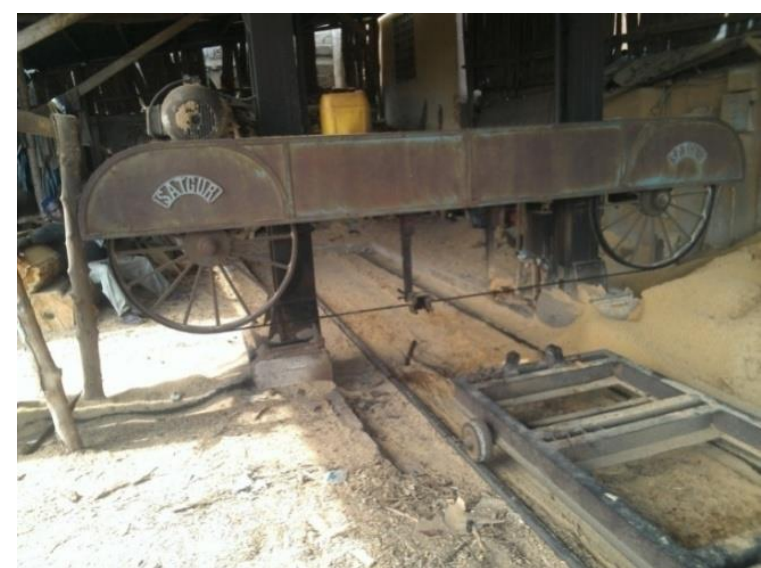

Figure 4: Typical example of squaring machine in Lomé in 2014

The observed losses induced by selling teak wood on the international market (cases of squares and logs when the price is minimal) could partially justify the choice of some national operators to sell their teak locally to local representatives of foreign importing companies. Indeed, the study of the financial profitability of the local sale of teak wood to foreign companies induces net earnings of about $128941 \mathrm{XOF}$ and $225682 \mathrm{XOF}$ respectively for logs and squares for a 20 - foot container (Gatonnou and al., 2015). The behaviour of these national operators reveals a problem of access to information on the international market for teak wood. Moreover, the waste trade can help mitigate losses observed on the international market.

\section{Conclusion}

This research on the incidence of the forest tax system on the competitiveness of teak wood in Togo reveals that the sale of squared teak except on the international market benefits the country in the current context of trade of this product. Indeed, the sale of squared teak wood on the international market generates losses of about 234734 to 489530 XOF per 20 - foot container given their price on that market. Currently, its export benefits from a positive protection as subsidy varying between $22.82 \%$ and $39.89 \%$ when reference prices are between 367 and $418 \mathrm{USD} / \mathrm{m}^{3}$. Concerning teak logs, Togo has a comparative advantage when the international price of this resource is at its highest level. In this specific case, the exporters give up an additional income of 517422 XOF per 20 foot container by agreeing to sell their wood locally when the international reference price is $542 \mathrm{USD} / \mathrm{m}^{3}$. This scenario also shows that, when the international price of teak $\log$ is at it is highest level; Togo does not protect its national market enough. This situation is expressed by a negative subsidy rate $(-19.11 \%)$.

In the light of these results, the promotion of modern industries for wood processing will lead comparative advantage gains from processed teak 
wood and to increased jobs creation. The achievement of this attractive goal requires a public private partnership through fiscal incentives. Furthermore, the public institutions in charge of trade and forest resources will have to set up a mechanism for dissemination international market prices..This will enable national operators to take advantage of better prices in the process of decisions making of selling teak logs.

\section{References:}

1. Akpoto, K., Kokutsè, A. D., Radji, R., Adjonou, K., Kokou, K., (2015). Impact of Small-Scale Logging in Semi Deciduous Forest of Togo (West Africa). Journal of Biodiversity Management and Forestry 4: 1. doi:10.4172/2327-4417.1000138.

2. Allaya, M., Karray, B., (2000). Comparative advantage of the production of oil olives in the Sfax region (Tunisia). MEDTT 2: $24-$ 29, French.

3. Amoah, M., Becker, G., Nutto, L., (2009). Effects of log export proclamation policy and dynamics of global tropical wood market one the growth of timber industry in Ghana. Journal of Forest Economics 15: $167-185$.

4. Aquilas, F., Adégbola, Y. P., Samey, N., Clohounto, J., Soglo, Y. Y., (2013). Analysis of the competitiveness of the added value chain of fresh shrimp and smoked shrimp from Benin. Invited paper presented at the 4th International Conference of the African Association of Agricultural Economists, September 22-25, 2013, HammametTunisia. French

5. DGSCN, (2013). The fourth general census of the population and housing. November, 2010. Final report, Special volume, Lomé-Togo. French

6. Dieng, A., Sagna, M., Babou, M., Dione, F., (2011). Analysis of the competitiveness of the rice sector in the valley of the river and the basin of Anambé in Senegal. Final report, Program of strengthening and survey on the food safety in West Africa (PRESAO), University of Michigan, USA. French

7. Direction of Planning (DP), (2009). Monograph of Golf Dictrict. Lomé - Togo. French.

8. Ed Perry, E., Abediang, K., (2009). Study of the wood sector in Cameroon, identification of job purveyor intervention. Final report of the Ministry of Employment and Vocational Training, Yaoundé, Cameroon. French.

9. Gatonnou, K. M., Agbodji, E. A., Kokutse, A. D., Kokou K., (2014). Analysis of the constraints of performance of the exportation market 
of teak wood in Togo. Togolese Review of Sciences 8 (2): 33 - 65. French.

10. Gatonnou, K. M., Agbodji E A, Kokutse, A. D., Kokou K., (2015). Contribution of the export of teak logs and squared to the economy of Togo. Journal of Scientific Research of the University of Lomé (Togo), Series C, 17 (3): 501 - 518. French.

11. Goodland, R., Daly, H., (1996). If tropical log export bans are so perverse, why are there so many? Ecological economics 18 (1996) : 189 - 196.

12. Guéneau, S., (2004). Forest fiscal system. Natural resources, Ideas for the debate 19, Iddri, 6 p. French.

13. ITTO, (2010). Clarification on Gabon log ban. Tropical timber market report, 15 (3): 1 - 20.

14. Kaplinsky, R., Terheggen, A., Tijaja, J., (2011). China is a final market: The Gabon timber and Thai Cassava value chains. World Development39 (7): 1177-1190.

15. Karsenty, A., Piketty, M. G., (1996). Strategy of industrialization based on the forest resource and irreversibilities. The limits of the Indonesian experience. Third World Review146: 431-451. French

16. Karsenty, A., (2000). Economic instruments for tropical forests : The Congo Basin Case. Instruments for sustainable private sector forestry series. International Institute for Environment and Development, London, United Kingdom.

17. Kishor, N., Mani, M., Constantino, L., (2004). Economic and environmental benefits of eliminating log exports. The case of Costa Rica. World Economy 27 (4): 609 - 624.

18. Van Kooten, G. C., (2014). Benefits and costs of impeding free trade: Revisiting British Columbia's restriction on log exports. Journal of Forest Economics 20: 333-347.

19. Monke, E. A., Pearson, S. R., (1989). The policy analysis matrix for agricultural development. Ithaca Cornell University press, New York, USA.

20. OAB, (2004). Promotion of more elaborate transformation of tropical wood in Africa. Action plan proposed by the ministerial conference, draft developed within the framework of the OIBT PPD 15/18Rev.2. French

21. OIBT, (2015). Suspension of the wood trading within the Yunnan borders. Markets news service report. French

22. Resosudarmo, B. P., Arief, A. Y., (2006). Is the log export ban an efficient instrument for economic development and environmental protection? The case of Indonesia. Asian Economic Papers 5 (2): 75 104. 
23. Shepherd, A. W., (2007). A guide to marketing costs and how to calculate them - Revised and reprinted, FAO, Rome - Italy.

24. Tachibana, S., (2000). Impacts of log export restrictions in Southeast Asia on the Japanese plywood market: an econometric analysis. Journal of forest research 5: $51-57$.

25. Tallec, F., Bockel, L., (2005). The by sector approach: analysis at the reference price. On line resource for policies elaboration (EASYPOL), FAO, Rome - Italy. 